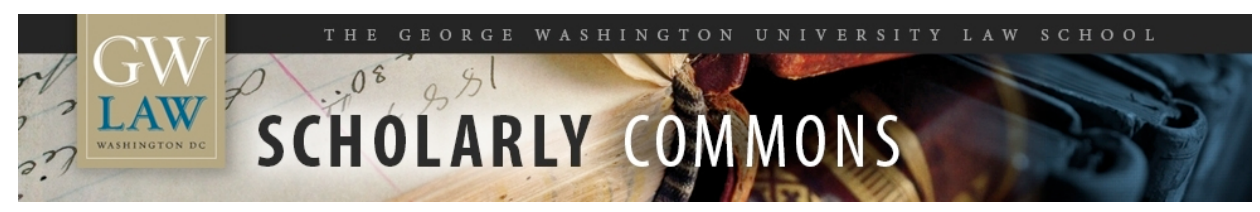

\title{
Public Safety and the Right to Bear Arms
}

Robert J. Cottrol

George Washington University Law School, bcottrol@law.gwu.edu

Raymond T. Diamond

Follow this and additional works at: https://scholarship.law.gwu.edu/faculty_publications

Part of the Law Commons

\section{Recommended Citation}

Robert J. Cottrol \& Raymond T. Diamond, Public Safety and the Right to Bear Arms in THE BILL OF RIGHTS IN MODERN AMERICA (David J. Bodenhamer, James W. Ely, Jr., eds., Indiana University Press, 2008).

This Book Part is brought to you for free and open access by the Faculty Scholarship at Scholarly Commons. It has been accepted for inclusion in GW Law Faculty Publications \& Other Works by an authorized administrator of Scholarly Commons. For more information, please contact spagel@law.gwu.edu. 


\title{
Pre-Publication Final Public Safety and the Right to Bear Arms
}

\section{Robert J. Cottrol and Raymond T. Diamond}

\author{
A well regulated Militia, being necessary to the \\ security of a free State, the right of the people to \\ keep and bear Arms, shall not be infringed. \\ (Second Amendment, U.S. Constitution)
}

On Tuesday November $20^{\text {th }}, 2007$ the United States Supreme Court granted certiorari in a case involving the District of Columbia's ban on handguns. The statute had been successfully challenged in the United States Court of Appeals for the District of Columbia Circuit on the grounds that it violated the Second Amendment's guarantee of "the right of the people to keep and bear arms.” With its decision to grant certiorari, the Supreme Court entered a constitutional controversy from which it had been largely absent for nearly seventy years, the meaning and scope of the Second Amendment. That controversy, the debate over the Second Amendment has occupied a somewhat curious place in American constitutional discourse. It is the subject of a vast polemical literature in the popular press, part of the often strident debate over gun control. Where once the amendment suffered from an unfortunate scholarly neglect, it has over the last two decades, become an arena of lively and sometimes acrimonious debate among historians, legal scholars and political scientists. The Court's decision is likely to provide a definitive legal ruling on the amendment although it is unlikely to end the controversy over the 
amendment's original meaning and how it should be applied in modern America. ${ }^{1}$

Briefly stated, the debate over the Second Amendment is part of the larger debate over gun control, and as such it focuses on whether or not the framers intended to limit the ability of government to prohibit or severely restrict private ownership of firearms. It is a debate fueled, in part, by the fear generated by this nation's high crime rate, including an average of 10,000 homicides committed annually with firearms. The debate is also fueled by the existence of broad public support for firearms ownership for self-defense and the fact that roughly half the homes in the country have firearms. ..

Two interpretations, broadly speaking, of the amendment have emerged from the debate. Some students of the Second Amendment stress the amendment's militia clause arguing either that the constitutional provision was only meant to insure that state militias would be maintained against potential federal encroachment or that the individual's right to keep and bear arms was meant to be protected only within the context of a highly regulated, regularly drilling state militia. Adherents of both variants of what might be called the collective rights view argue that the Second Amendment poses little in the way of an impediment to strict, even prohibitory gun control given the fact that most Americans at the start of the twenty-first century are not regularly engaged in the business of militia training.

Supporters of the individual rights view stress the amendment's second clause, arguing that the framers intended a militia of the whole, or at least a militia consisting of the entire ablebodied white-male population. For them this militia of the whole was expected to perform its duties with privately owned weapons. Advocates of this view also urge that the militia clause 
should be read as an amplifying rather than a qualifying clause; that is, while maintaining a "well-regulated militia” was a major reason for including the Second Amendment in the Bill of Rights, it should not be viewed as a sole or limiting reason. The framers also had other reasons for proposing the amendment, including a right to individual self-defense.

The right to keep and bear arms became controversial in the late twentieth century, yet for much of American history constitutional commentators extolled the right as a fundamental cornerstone of liberty that could not be denied free people. This widespread agreement occurred in part because of the frontier conditions that existed from the colonial period through much of the nineteenth century. The role of privately owned arms in achieving American independence, particularly in the early years of the Revolution, strengthened this consensus. The often violent and lawless nature of American society also contributed to the widespread view that the right to possess arms for self-defense was fundamental.

But the Second Amendment and the right to keep and bear arms cannot be understood solely through an examination of American history. Like other sections of the Bill of Rights, the Second Amendment was an attempt to secure what was believed to be a previously existing right. The framers of the Bill of Rights did not believe they were creating new rights. Instead, they were attempting to prevent the newly formed federal government from encroaching on rights already considered part of the English constitutional heritage. ${ }^{2}$

To understand what the framers' intended the Second Amendment to accomplish, it is necessary to examine their world and their view of the right to bear arms as one of the traditional “rights of Englishmen.” The English settlers who populated North America in the seventeenth 
century were heirs to a tradition over five centuries old governing both the right and the duty to be armed. At English law the idea of an armed citizenry responsible for the security of the community had long coexisted, perhaps somewhat uneasily, with regulation of the ownership of arms, particularly along class lines. The Assize of Arms of 1181 required the arming of all free men. Lacking both professional police forces and a standing army, English law and custom dictated that the citizenry as a whole, privately equipped, assist in both law enforcement and military defense. By law all men ages 16 through 60 were liable to be summoned into the sheriff's posse comitatus. All persons were expected to participate in the hot pursuit of criminal suspects, the "hue and cry," supplying their own arms for the occasion. There were legal penalties for failure to participate. The maintenance of law and order was a community affair, a duty of all citizens. ${ }^{3}$

And all able-bodied men were considered part of the militia and were required, at least theoretically, to be prepared to assist in military defense. The law required citizens to possess arms. Towns and villages were required to provide target ranges in order to maintain the martial proficiency of the yeomanry. Despite this, the English discovered that the militia of the whole maintained a rather indifferent proficiency and motivation. By the sixteenth century the practice was to rely on select bodies of men intensively trained for militia duty rather than on the armed population at large.

Although English law recognized a duty and a right to be armed, both were highly circumscribed by English class structure. The law regarded the common people as participants in community defense, but it also regarded them as a dangerous class, useful perhaps in defending shire and realm but also capable of mischief with their weapons, mischief toward each other, their betters, and their betters' game. Restrictions on the type of arms deemed suitable for 
common people had also long been part of English law and custom. Game laws had long been one tool used to limit the arms of the common people. The fourteenth-century Statute of Northampton restricted the ability of people to carry arms in public places. A sixteenth-century statute designed as a crime control measure prohibited the carrying of handguns and crossbows by those with incomes of less than 100 pounds a year. After the English Reformation, Catholics were also often subject to being disarmed as potential subversives.

The need for community security had produced a traditional duty to be armed at English law, but it took the religious and political turmoil of seventeenth-century England to transform that duty into a notion of a political or constitutional right. Attempts by Stuart Kings Charles II and James II to disarm large portions of the population, particularly Protestants and suspected political opponents, met with popular resistance and helped implant into English and later American constitutional sensibilities the belief that the right to possess arms was of fundamental political importance. These efforts led to the adoption of the seventh provision of the English Bill of Rights in 1689:

"That the subjects which are Protestants may have arms for their defense suitable to their conditions and as allowed by law." ${ }^{4}$

By the eighteenth century, the right to possess arms, both for personal protection and as a counterbalance against state power, had come to be viewed as one of the fundamental rights of Englishmen on both sides of the Atlantic. Sir William Blackstone, whose Commentaries on the Laws of England greatly influenced American legal thought both before the Revolution and well into the nineteenth century, listed the right to possess arms as one of the five auxiliary rights of English 
subjects without which their primary rights could not be maintained:

The fifth and last auxiliary right of the subject, that I shall at present mention, is that of having arms for their defense, suitable to their condition and degree and such as are allowed by law. Which is also declared by the same statute ... and is indeed a public allowance, under due restrictions, of the natural right of resistance and self-preservation, when the sanctions of society and laws are found insufficient to restrain the violence of oppression.

If some five centuries of English experience had transformed the duty to be armed for the common defense into a right to be armed, in part, to resist potential political oppression, a similar evolution in thought had occurred in the American colonies between the earliest seventeenthcentury settlements and the American Revolution. Early English settlement in North America had a quasi-military character, an obvious response to harsh frontier conditions. Governors of settlements often held the title of militia captain, reflecting both the civil and military nature of their office. In order to provide for the defense of often isolated colonies, special effort was made to insure that white men, capable of bearing arms, were brought into the colonies.

Far from the security of Britain and often facing hostile European powers at their borders, colonial governments viewed the arming of able-bodied white men and the requirement for militia service as essential to a colony’s survival. The right and duty to be armed broadened in colonial America. If English law qualified the right to own arms by religion and class, those considerations were significantly less important in the often insecure colonies. If by the seventeenth century the concept of the militia of the whole was largely theoretical in England, in America it was the chief instrument of colonial defense. While the English upper classes sought to restrict the ownership of arms on the part of the lower classes in part as a means of helping to enforce game laws, there were significantly fewer restrictions on hunting in North America with its small population and abundant 
game. From the beginning, conditions in colonial America created a very different attitude toward arms and the people.

Race provided another reason for the renewed emphasis on the right and duty to be armed in America. Britain’s American colonies were home to three often antagonistic races — red, white, and black. For the settlers of British North America, an armed and universally deputized white population was necessary not only to ward off dangers from the armies of other European powers but also to ward off attacks from the indigenous Indian population that feared the encroachment of English settlers on their lands. And an armed white population was essential to maintain social control over blacks and Indians who toiled unwillingly as slaves and servants in English settlements. This helped broaden the right to bear arms for whites. The need for white men to act not only in the traditional militia and posse capacities but also to keep order over the slave population helped lessen class, religious, and ethnic distinctions among whites in colonial America. That need also helped extend the right to bear arms to classes traditionally viewed with suspicion in England, including indentured servants.

The colonial experience helped strengthen the appreciation of early Americans for the merits of an armed citizenry. That appreciation was of course further strengthened by the experience of the American Revolution. The Revolution began with acts of rebellion by armed citizens. And if sober historical analysis reveals that it was actually American and French regulars who ultimately defeated the British and established American independence, the image of the privately equipped rag-tag militia successfully challenging the British empire earned a firm place in American thought and helped influence American political philosophy. For the generation that authored the Constitution, it reinforced the lessons their English ancestors had learned in the 
seventeenth century. It revitalized Whiggish notions that standing armies were dangerous to liberty. It helped transform the idea that the people should be armed and security provided by a militia of the people from a matter of military necessity into a political notion, one that would find its way into the new Constitution.

This view that an armed population contributed to political liberty as well as community security found its way into the debates over the Constitution and is key to understanding the Second Amendment. Like other provisions of the Constitution, the clause that gave Congress the power to provide for organizing, arming, and disciplining the militia excited fears among those who believed that the proposed Constitution could be used to destroy both state power and individual rights. It is interesting, in light of the current debate over the meaning of the Second Amendment, that both Federalists and Anti-Federalists assumed that the militia would be one that enrolled almost the entire white-male population between the ages of 16 and 60 and that militia members would supply their own arms.

But many feared that the militia clause could be used both to do away with the state's control over the militia and to disarm the population. Some expressed fear that Congress would use its power to establish a select militia. Many viewed a select militia with as much apprehension as they did a

standing army. The English experience of the seventeenth century had shown that a select militia could be used to disarm the population-at-large. Richard Henry Lee of Virginia expressed the fear that a select militia might serve this end. ${ }^{6}$

In their efforts to answer critics of the Constitution, Alexander Hamilton and James Madison addressed the charges of those critics who argued that the new Constitution could destroy both the 
independence of the militia and deny arms to the population. Hamilton's responses are particularly interesting because he wrote as someone who was openly skeptical concerning the military value of the militia of the whole. The former Revolutionary War artillery officer conceded that the militia had fought bravely during the Revolution, but he argued it proved no match when pitted against regular troops. Hamilton urged the creation of a select militia that would be more amenable to military training and discipline than the population as a whole. Despite this he conceded that the population as a whole should be armed.

But if Hamilton gave only grudging support to the concept of the militia of the whole, Madison, author of the Second Amendment, was a much more vigorous defender of the concept. In The Federalist, Number 46, he left little doubt that he saw the armed population as a potential counterweight to tyranny:

[L]et a regular army, fully equal to the resources of the country, be formed; and let it be entirely at the devotion of the federal government: still it would not be going too far to say that the State governments with the people on their side would be able to repel the danger. The highest number to which according to the best computation, a standing army can be carried in any country does not exceed one hundredth part of the whole number of souls; or one twenty-fifth part of the number able to bear arms. This proportion would not yield, in the United States an army of more than twenty-five or thirty thousand men. To these would be opposed a militia amounting to near half a million citizens with arms in their hands, officered by men chosen among themselves, fighting for their common liberties and united and conducted by governments possessing their affections and confidence. It may well be doubted whether a militia thus circumstanced could ever be conquered by such a proportion of regular troops. Those who are best acquainted with the late successful resistance of this country against the British arms will be most indined to deny the possibility of it. Besides the advantage of being armed, which the Americans possess over the people of almost every other nation, the existence of subordinate governments, to which the people are attached and by which the militia officers are appointed, forms a barrier against the enterpnses of ambition, more insurmountable than any which a simple government of any form can admit of notwithstanding the military establishments in the several kingdoms of Europe, which are carried as far as the public resources will bear, the governments are afraid to trust the people with arms.

This desire to maintain a universal militia and an armed population played a critical part in the adoption 
of the Second Amendment. The amendment, like other provisions of the Bill of Rights, was designed to prevent the newly created federal government from encroaching on rights already enjoyed by the people. It is important to remember that firearms ownership, for self-defense and hunting, was widespread with few restrictions, at least for the white population. It is also significant that the universally accepted view of the militia, at the time, was that militiamen would supply their own arms. One year after the ratification of the Bill of Rights Congress passed legislation reaffirming the notion of a privately equipped militia of the whole. The act, titled "An Act more effectually to provide for the National Defense by establishing an Uniform Militia throughout the United States,” called for the enrollment of every free, able-bodied white-male citizen between the ages of 18 and 45 into the militia. The act required every militia member to provide himself with a musket or firelock, a bayonet, and ammunition. ${ }^{8}$

The decades between the adoption of the Second Amendment and the Civil War brought little opportunity for judicial interpretation of the constitutional provision. While a number of jurisdictions had laws prohibiting the carrying of concealed weapons, there were few restrictions concerning the ownership or the open carrying of arms in antebellum America. Most laws restricting the possession of firearms were to be found in the slave states of the antebellum South. These laws generally prohibited the possession of firearms on the part of slaves and free blacks. Outside of the slave states the right to have arms was generally not impaired, not even for free Negroes. There was no federal legislation restricting firearms ownership, and since Barron v. Baltimore (1833) held that the Bill of Rights only limited the power of the federal government, there was no occasion before the Civil War for the federal courts to examine the issue.

If in the antebellum era there was an absence of federal court decisions on the Second Amendment, there was nonetheless widespread agreement concerning the scope and meaning of the provision among antebellum commentators and in the limited number of state court decisions 
that examined the issue. Noted jurist and legal commentator St. George Tucker contrasted the Second Amendment's robust guarantee of a right to keep and bear arms with the more restrictive English guarantee, noting that class restrictions and game laws had not limited the American right in the way that the English right had been limited. Supreme Court Justice Joseph Story also regarded the right as fundamental:

The right of the citizens to keep, and bear arms has been justly considered, as the palladium of the liberties of a republic; since it offers a strong moral check against the usurpation and arbitrary power of rulers; and will generally, even if they are successful in the first instance, enable the people to resist, and triumph over them. ${ }^{9} 8$

If leading antebellum commentators saw the right as central to a free people, federal courts were largely silent on the subject. The only pronouncement from the Supreme Court on the subject before the Civil War came m Justice Taney’s opinion in Dred Scott v. Sandford (1857). Taney indicated that African Americans, slave or free, could be denied the right to possess arms just as they could be denied freedom of speech, assembly, and travel. Despite the silence of the federal courts on the subject, state courts began developing a jurisprudence of the right to keep and bear arms, interpreting relevant provisions of state constitutions. These cases attempted to balance the right to bear arms against competing interests in public safety. Generally state courts upheld prohibitions against carrying concealed weapons. Some state courts limited the right to carry arms to those weapons that were suitable for use in "civilized warfare," an attempt to prohibit the carrying of weapons that were thought to be used exclusively for criminal purposes. Most of these cases involved restrictions on carrying concealed firearms. In one antebellum case the Georgia Supreme Court decided that the Second Amendment applied to that state. ${ }^{109}$ 
It would take the turmoil of the Civil War and Reconstruction to bring the Second Amendment before the Supreme Court. The end of the Civil War brought about a new conflict over the status of former slaves and the power of the states. The defeated white South sought to preserve as much of the antebellum Southern social order as could survive Northern victory and national law. Southern states were not prepared to accord to the newly emancipated black population the general liberties enjoyed by white citizens. Indeed, former slaves did not even have the rights that Northern states had long given free Negroes.

In 1865 and 1866 Southern states passed a series of statutes known as the black codes. These statutes were designed, in part, to insure that traditional Southern labor arrangements would be preserved. They often required blacks to sign labor contracts that bound black agricultural workers to their employers for a year. Blacks were forbidden from serving on juries and could not testify or act as parties against whites. Vagrancy laws were used to force blacks into labor contracts and to limit freedom of movement. And as further indication that the former slaves had not yet joined the ranks of free citizens, Southern states passed legislation prohibiting blacks from carrying firearms without licenses, a requirement to which whites were not subjected. The Mississippi statute provides a typical example of restrictions of this kind:

Be it enacted,... that no freedman, free Negro or mulatto, not in the military service of the United States government, and not licensed so to do by the board of police of his or her county, shall keep or carry firearms of any kind, or any ammunition, dirk or bowie knife, and on conviction thereof in the county court shall be punished by fine, not exceeding ten dollars, and pay the cost of such proceedings and all such arms or ammunition shall be forfeited to the informer; and it shall be the duty of every civil or military officer to arrest any such freedman, free Negro or mulatto found with any such arms or ammunition, and shall cause him or her to be committed to trial in default of bail. ${ }^{11} 10$ 
Such measures caused strong concerns among Northern Republicans. Many charged that the South was trying to reinstate slavery and deny former slaves those rights long considered essential to a free people. The news that the freedmen were being deprived of the right to keep and bear arms was of particular concern to champions of Negro citizenship. For them the right of the black population to possess weapons went beyond symbolic importance. It was important both as a means of maintaining the recently reunited union and as a means of insuring against the virtual reenslavement of those formerly in bondage. Faced with a hostile South determined to preserve the antebellum social order, Northern Republicans were particularly alarmed at provisions that preserved the right to keep and bear arms for former Confederates while disarming blacks, the one group in the South with clear unionist sympathies. This helped convince many Northern Republicans to seek national enforcement for the Bill of Rights.

The debates over the Fourteenth Amendment and the civil rights legislation of the Reconstruction era suggest the determination of Congress to protect the right to keep and bear arms and other provisions of the Bill of Rights against state infringement. Representative Jonathan Bingham of Ohio, who authored the Fourteenth Amendment's privileges or immunities clause, and other Republican supporters of the Fourteenth Amendment expressed the view that the clause applied the Bill of Rights to the states. The Southern efforts to disarm the freedmen and to deny other basic rights to former slaves played an important role in convincing the 39th Congress that traditional notions concerning federalism and individual rights needed to change. ${ }^{12}$

If the events of Reconstruction persuaded the 39th Congress of the need for applying the Bill of Rights to the states, the Supreme Court in its earliest decisions on the Fourteenth Amendment moved to maintain the antebellum federal structure. The Supreme Court's first pronouncements on 
the Second Amendment came about after the enactment of the Fourteenth Amendment and concerned the extent to which the latter amendment extended the protection of the right to keep and bear arms. The first case, United States v. Cruikshank (1875), stemmed from charges brought by federal officials against William Cruikshank and others for violating the constitutional rights of a group of black men who were attempting to vote. The charges included claims that Cruikshank and his associates violated the right of the black men to peaceably assemble and that they also violated their right to bear arms. The Court in a majority opinion authored by Chief Justice Morrison R. Waite held that the federal government had no power to protect citizens against private action that deprived them of their constitutional rights. The opinion held that the First and Second Amendments were limitations on Congress, not private individuals. For protection against private criminal action the individual was required to look to state governments. ${ }^{13}$

The next case in which the Court examined the Second Amendment, Presser v. Illinois, more directly involved the question of whether or not the Second Amendment in combination with the Fourteenth set limits on the ability of states to limit the right to bear arms. That case involved a challenge to an Illinois statute that prohibited individuals who were not members of the organized militia from parading with arms. Justice William Woods' majority opinion noted that the statute did not infringe on the right to keep and bear arms. Woods nonetheless used the case to indicate that the Second Amendment did not apply to state governments even in light of the Fourteenth Amendment. Woods also indicated that because the citizenry at large constituted a reserve militia that was a resource for the United States government and hence could not be disarmed by state governments, independent of Second Amendment considerations. Presser is still cited as 
precedent indicating that the Fourteenth Amendment does not incorporate the Second Amendment. ${ }^{14}$

The nineteenth century would come to an end with legal commentators in general agreement that the right to keep and bear arms was an important one for a free people. Michigan jurist Thomas M. Cooley discussed the subject in his treatise on constitutional law. Anticipating some of the modern debate on the subject, Cooley expressed the view that the amendment should not be seen as restricted only to members of the militia. He noted that the purpose of the Second Amendment was to allow the people to provide a check against potential governmental usurpation of power. Cooley went on to note that a restriction of the right to arms to members of the militia, whose membership could be limited by the government, would allow the government to defeat the very purpose of the amendment. ${ }^{15}$

The nineteenth century would end with reasonably broad agreement among those constitutional commentators who considered the issue that the right to have arms was an important safeguard for the freedoms of the American people. It should be added that that agreement was a broad agreement in principle that usually did not extend to the messy details of what kinds of firearms regulation were and were not consistent with the principle. Because firearms regulation was a matter of state and local law, the federal courts, adhering to the view that the Second Amendment did not apply to the states, had little to say on the subject.

State courts did develop a jurisprudence on the right to have arms examining state firearms regulation in light of provisions in state constitutions protecting the right to have arms. These cases usually provided state and local governments more leeway in regulating the carrying of arms, particularly concealed weapons, than in restricting the ownership of arms. Thus the 1871 
Tennessee case of Andrews v. State held that the right to bear arms was an incident of militia service and subject to reasonably broad state regulation, while the right own arms was a private right with limitations on state restriction. ${ }^{16}$

The early twentieth century would bring about new efforts at firearms regulation and with it new attitudes concerning arms and the Second Amendment. Traditional beliefs concerning the importance of arms were frequently being tempered by the view that whole classes of people were unfit to exercise this prerogative. In the South, state governments, freed from the federal scrutiny that existed in the Reconstruction era, used laws regulating concealed weapons to accomplish what had been attempted with the postwar black codes. Discriminatory enforcement of these laws often left blacks disarmed in public places while whites remained free to carry firearms. This state of affairs helped facilitate lynchings and other forms of racial violence during the Jim Crow era.

But the South was not the only region where social prejudice restricted the right of disfavored minorities to possess firearms. If the white South saw armed blacks as a threat, politicians in other regions saw a similar threat arising from large-scale Southern and Eastern European immigration. The new immigrants, like others before them, often met hostile receptions. They were associated with crime and anarchy and stereotyped as lazy and mentally unfit. Many native-born Americans feared the immigrants would bring anarchist-inspired crime from Europe, including political assassinations and politically motivated armed robberies. These fears led in 1911 to passage of New York’s Sullivan Law. This state statute was aimed at New York City, a place where the large, foreign-born population was believed to be peculiarly susceptible to crime and vice. The Sullivan Law went far beyond typical gun control measures of the day. It prohibited the 
unlicensed carrying of weapons and required a permit for the ownership or purchase of pistols. Violation of the statute was a felony. The first person convicted under the statute was a member of one of the suspect classes, an Italian immigrant. ${ }^{17}$

It was in this early twentieth century atmosphere that the collective rights view of the right to bear arms first began to attract the attention of the judiciary. In one of the earliest cases to adopt this view Salina v. Blaksley, the Supreme Court of Kansas interpreted that state's constitutional provision protecting the right to bear arms as a protection that only applied to the militia and not for individual purposes. ${ }^{18}$ In 1911 Maine Chief Justice Lucillius A. Emery authored an essay “The Constitutional Right to Keep and Bear Arms” in the Harvard Law Review urging that the right to bear or carry arms should be viewed as a right limited to militia service. He also noted that legislatures could not prohibit the keeping or ownership of arms, echoing the distinction made by the Tennessee Court in Andrews. ${ }^{19}$

These developments affected relatively few Americans at the beginning of the twentieth century. The nation was still largely rural. Firearms ownership for both self defense and hunting were fairly commonplace. And statutes regulating firearms ownership were relatively rare and unobtrusive. For most citizens access to firearms was largely unimpaired and there was not too much occasion for either the courts or constitutional commentators to say much concerning the Second Amendment.

This situation would change after the First World War. Prohibition brought about the rise of organized gangs engaged in the sale of bootlegged alcohol. Territorial rivalries among the gangs led to open warfare on the streets of the nation's major cities. That warfare was made even more terrifying by the introduction of a terrifying new weapon, the Thompson submachine gun. A fully 
automatic weapon, developed too late for use in World War I, the “Tommy Gun” was one of the first submachine guns in widespread use. Used by violent criminals in their wars on each other, the Thompson also claimed the lives of a fair number of members of the general public as well.

The end of the twenties and the end of prohibition did not bring a halt to notorious misuse of automatic weapons. The rise in the 1930s of such desperadoes as John Dillinger, "Pretty Boy” Floyd, “Ma” Barker, George “Machine Gun” Kelly, and Clyde Barrow and Bonnie Parker became a part of American folklore. The exploits of such criminals were made more vivid and terrifying by the new medium of talking motion pictures. Thus, the horrors of criminal misuse of automatic weapons were forcibly brought home to the public.

These events caused the Roosevelt administration to propose the first federal gun control legislation. The National Firearms Act of 1934 required registration, police permission, and a prohibitive tax for firearms that were deemed gangster weapons, including automatic weapons, sawed-off shotguns, and silencers. It is interesting in light of the current debate that the Roosevelt administration deemed the act a revenue measure, conceding that an outright ban on such weapons would probably be beyond Congress’ powers.

The 1934 act gave rise to the Supreme Court's last decision to date on the Second Amendment, United States v. Miller. It was a curious case. Both sides of the Second Amendment debate have claimed that the decision authored by Justice James C. McReynolds supports their views. Interestingly, the Court only heard arguments by the government. The federal government appealed a decision by a federal district court invalidating the National Firearms Act of 1934 in a case involving the unlicensed transportation of an unregistered sawed-off shotgun. The Court focused on the weapon in question: 
In the absence of any evidence tending to show that the possession of a [sawed-off shotgun] at this time has some reasonable relationship to the preservation or efficiency of a well regulated militia, we cannot say that the Second Amendment guarantees the right to keep and bear such an instrument. Certainly it is not within judicial notice that this weapon is any part of the ordinary military equipment or that its use could contribute to the common defense. ${ }^{20}$

Advocates of the collective rights view have emphasized the Miller Court's focus on the militia, claiming that it was an indication that the Court saw the Second Amendment as only being concerned with the preservation of state militias. But the Miller Court's discussion of the militia indicates that the Court saw a clear relationship between the individual right and the maintenance of the militia:

The signification attributed to the term Militia appears from the debates in the Convention, the history and legislation of Colonies and States, and the writings of approved commentators. These show plainly enough that the Militia comprises all males physically capable of acting in concert for the common defense. "A body of citizens enrolled for military discipline.” And further, that ordinarily when called for service these men were expected to appear bearing arms supplied by themselves and of the kind in common use at the time. ${ }^{21}$

Probably the most accurate way to view what the Court did in Miller is to see it as an updating of the nineteenth-century civilized warfare doctrine. McReynolds's decision relied on the antebellum Tennessee case Avmette v. State, which allowed the state to restrict the carrying of those types of weapons which were frequently used by criminals and not suitable for the common defense. The Supreme Court in Miller remanded the case to the lower courts to determine whether or not a sawed-off shotgun was a weapon appropriate for militia use. That determination was never made. ${ }^{22}$

Although Miller was the Court's most comprehensive exploration of the Second Amendment, it had little 
effect on either firearms regulation or the general public's view concerning the right to keep and bear arms. For nearly three decades after Miller little existed in the way of federal firearms regulation. State and local legislation existed, but with few exceptions such as the New York Sullivan Law, these were usually traditional regulations governing the manner of carrying weapons, not outright prohibitions. There was little serious attempt to mount constitutional challenges to these restrictions. The Second Amendment was thus bypassed in the postwar Supreme Court's process of applying most of the provisions of the Bill of Rights to the states. Justice Hugo Black, who was an advocate of the view that the Fourteenth Amendment made all of the Bill of Rights applicable to the states, argued that the Second Amendment should also apply to the states, but the Court has not heard a case on that issue since Presser. It is probably accurate to say that at least until the 1960 s most people, including attorneys and judges, accepted the view that the Second Amendment protected an individual right but otherwise thought very little about the matter because firearms restrictions, even on the state and local levels, were slight.

It would take the turmoil of the 1960s and the tragedy of three assassinations to bring about the birth of the modern gun control movement and create the current debate over the meaning of the Second Amendment. The assassination of President John F. Kennedy in 1963 brought calls for stricter national controls over the sale of firearms. Urban riots and the assassinations of civil rights leader Martin Luther King and Senator Robert F. Kennedy helped lead to the passage of the Gun Control Act of 1968, the first federal legislation that seriously affected the purchasing of firearms for large numbers of Americans. This legislation limited the purchase of firearms through the mails and also restricted the importation of surplus military rifles. The act also prohibited the purchase of firearms by those with felony convictions, even though the legislation provided no means of checking a purchaser's record. Some of the provisions of the 1968 act would later be modified by legislation passed in 1986.

The 1968 act proved to be something of a watershed. Since then a national debate over gun control 
and a subsidiary debate over the meaning of the Second Amendment have become perennial features in American politics. The rise of a highly visible national gun control movement since the sixties during has been something new in American political life. Some adherents of this new political movement have advocated relatively moderate measures. These have included screening measures designed to prevent individuals with suspect backgrounds, criminal records or histories of mental instability from purchasing firearms. Such measures are essentially extensions of firearms regulations that have long existed in many states, attempts to limit firearms use by undesirable persons. These kinds of regulations have long existed even in states with state constitutional protection for the right to bear arms and courts willing to enforce such guarantees. The more modest measures pose little threat to the general public's right to possess firearms.

But since the 1960s, others have argued for more radical measures. Their view has been that state and local government and more importantly the federal government can and should outlaw the general public's right to possess whole categories of firearms that had previously been owned by large numbers of law-abiding citizens. Many in the gun control movement argued that ownership of guns for self defense or as part of a universal citizens' militia was dangerous and atavistic. They claimed that the only legitimate reason for civilian firearms ownership was for sporting purposes, usually hunting, and that even that ownership should be permitted only under stringent licensing. Efforts were made to ban firearms that did not meet this “sporting purposes” definition. In the 1970s and 1980s gun control advocates urged the banning of handguns, particularly cheap ones popularly known popularly as "Saturday Night Specials." In the 1990s many gun control supporters advocated bans on "assault weapons,” a term employed without great precision to include semiautomatic rifles with military features such as bayonet lugs and pistol grips, or virtually all semiautomatic rifles, depending on the 
user's definition. The gun control movement scored some success with its campaign against assault weapons. A handful of states enacted bans on some semi-automatic firearms. Congress enacted a ten year prohibition on the sale of semiautomatic rifles with military style features in 1994. Congress refused to renew the ban in 2004.

This advocacy of wholesale restrictions on firearms ownership helped bring about the modern debate over the meaning of the Second Amendment. Much of the effort to reinterpret the Second Amendment as a collective right has been an attempt to justify proposed firearms restrictions that at earlier periods in American history would have been regarded as unconstitutional. Since the 1960s a vigorous polemical debate over whether the amendment should be seen as a broad individual right or as a right limited to a highly controlled militia context has been waged in the nation's editorial pages and broadcast media.

Despite the passion with which the public debate has been waged, the Supreme Court has kept a curious silence on the issue. The Court has had opportunity to address the issue, the lower federal courts in the 1970s and 1980s upheld gun control legislation either by citing Miller for the proposition that the Second Amendment only protected the right to bear arms in a militia context when addressing federal legislation or Presser for the proposition that the amendment did not apply to the states. The Supreme Court declined to grant certiorari in these cases and provide a definitive modern ruling on the issue.

If the Court has been reluctant to directly address the issue of the Second Amendment and its applicability to the gun control issue, it has, curiously enough, been willing to acknowledge the right to bear arms as dicta in cases extraneous to the gun control issue. Starting with Justice Harlan’s dissent in the 1961 case Poe v. Ullman involving a Connecticut anti-contraception statute, the right to bear 
arms has frequently been noted in privacy cases:

"The full scope of the liberty guaranteed by the Due Process Clause cannot be found in or limited by the precise terms of the specific guarantees elsewhere provided in the Constitution. This 'liberty' is not a series of isolated points priced out in terms of the taking of property; the freedom of speech, press and religion; the right to keep and bear arms (italics added) ${ }^{23}$

Statements by other justices, sometimes in dicta, sometimes in statements to the press have given heart to supporters of either the individual or collective rights viewpoints, but the Court retained its institutional silence on the subject.

If the Supreme Court in recent decades has been reluctant to address the controversy, other important legal actors were making pronouncements on the Second Amendment and the right to arms more generally. Forty-four of the fifty states have right to keep and bear arms provisions in state constitutions. While the federal jurisprudence on the right is somewhat thin, state courts have developed a rather robust jurisprudence, ranging from a fairly restrictive to fairly expansive views of the right. Congress has also played a role in Second Amendment interpretation. In 1982 the Senate Judiciary Committee's Subcommittee on the Constitution issued a report supporting the individual rights view of the amendment. Four years later Congress passed the Firearms Owners Protection Act protecting the right of interstate travel with firearms. The state was prefaced with Congressional findings declaring the Second Amendment an individual right.

The 1980s would see the rise of the academic debate over the Second Amendment. At first it was a debate that mainly engaged independent scholars not affiliated with universities and usually connected to groups supporting or opposing stricter gun controls. Because the subject inherently 
involves a debate over original intentions or understandings, historians tended to enter the debate sooner than scholars in the legal academy. Something of a milestone in the history of the debate came in 1989 with the publication of Sanford Levinson's “The Embarrassing Second Amendment,” in the Yale Law Journal. For the first time since gun control had become a national issue in the 1960s, a major constitutional scholar in a leading law journal was arguing that the Second Amendment deserved a serious examination and that the individual rights view was likely the more accurate one. Levinson's article spurred other scholars in law, history and political science to take up the issue with such leading scholars as Akhil Amar, Saul Cornell, Leonard Levy, Jack Rakove, Laurence Tribe, William Van Alstyne and Gary Wiilis, among many others. ${ }^{24}$

The new scholarship probably played a part in reawakening interest on the part of the judiciary in the Second Amendment. Supreme Court Justice Clarence Thomas indicated a favorable disposition toward the individual rights reading of the amendment in the 1997 case United States v. Printz. ${ }^{25}$ Justice Scalia has expressed support for the individual rights view in scholarly commentary. A major breakthrough for individual rights advocates came in 2001 with the Fifth Circuit case United States v. Emerson. ${ }^{26}$ In Emerson, which involved a Second Amendment challenge to a prosecution of an individual who possessed a firearm in violation of a restraining order, the Fifth Circuit Court of Appeals held that the Second Amendment was an individual right but that a restraining order prohibiting possession of firearms on the part of an individual suspected of domestic violence was reasonable regulation. A 2002 decision by the Ninth Circuit Court of Appeals in Silveira v. Lockyer upheld California’s ban on assault weapons holding that the Second Amendment was a collective right The decision seemed written in part to rebut the Fifth Circuit’s opinion in Emerson.. ${ }^{27}$

National politics would also play a role in issues of Second Amendment interpretation. The election 
of George Bush in the very close election of 2000 brought to national office an administration that had enjoyed the support of the National Rifle Association which probably tipped the electoral balance in a number of states. One result of this was a new attitude in the Justice Department more supportive of the individual rights view than had been the case in recent decades. In 2004 the Attorney General's Office under Attorney General John Ashcroft’s direction issued a formal memorandum on the Second Amendment. issued The memorandum reflected Ashcroft's longstanding support for the individual rights interpretation. As might be expected, the memorandum met with strong criticism by proponents of stricter gun control and strong support by opponents. The Ashcroft memorandum was interesting for its detailed analysis of the history and meaning of the Second Amendment, reflecting much of the new scholarship that had developed since the 1990s. ${ }^{28}$

The debate continues into the twenty-first century. It continues to be waged in academic journals and the popular media. The Supreme Court still retains its institutional reluctance to enter the fray, although Chief Justice John Roberts in his 2005 confirmation hearing indicated that he believed the proper interpretation of the Second Amendment was still an open issue and one that the lower federal courts had not resolved. The political branches of government seem largely sympathetic to protecting the right to have arms. During the 1990s and continuing into the first decade of the twenty-first century an increasing number of states have passed legislation liberalizing the right of citizens to carry guns for self protection, a reflection of both public fears of crime and the political skill of the National Rifle Association. Some forty states have statutes permitting almost anyone eligible to own a firearm to obtain a license to carry a concealed weapon. In 2006 Congress passed legislation prohibiting lawsuits against firearms manufacturers for criminal misuse of firearms. The legislation contained findings that the Second Amendment protected a right of individuals regardless of whether or not they were 
members of the militia. That same year Congress also passed legislation prohibiting public officials from disarming citizens during times of natural disaster. This measure was enacted in part in response to actions taken by New Orleans officials during Hurricane Katrina. During that crisis New Orleans police confiscated guns from citizens in New Orleans, sometimes in dramatic confrontations played out on national television.

The March 2007 decision by the U.S. Court of Appeals for the D.C. Circuit overturning the District of Columbia's handgun ban on Second Amendment grounds undoubtedly played a key role in ending the Supreme Court’s traditional reluctance to consider Second Amendment cases.“ In a 2-1 decision in the case Parker v. District of Columbia, a three judge panel of the D. C. Circuit declared the District of Columbia.'s ban on handguns unconstitutional. The majority opinion authored by Judge Laurence H. Silberman of the D. C. Circuit held that the Second Amendment was a right of individuals and that the District of Columbia's ban contravened that right. It was the first time that a federal court had held that a specific piece of gun control legislation violated the Second Amendment The full D. C. Circuit denied the District of Columbia's petition for an en banc hearing or hearing by the full D. C. Circuit, thus letting the panel opinion stand. The government of the District of Columbia filed a petition for certiorari which was granted in November.

This chapter is being completed in early December of 2007. As we are writing parties and amici are preparing briefs for what will be the most important Second Amendment case in United States history. Oral arguments in the case involving the handgun ban in the District of Columbia will take place in the Spring of 2008 with a decision likely in the early summer. We, of course, do not know how the Court is going to rule but its decision is not likely to end the academic and popular debate over 
the amendment. The debate over arms and rights in contemporary America is fueled by mixed feelings and often contradictory impulses on the part of the American people. Times of crisis, natural disasters like Hurricane Katrina, or the attacks on 9/11 illustrate one dimension of the debate. During such occasions we often see media reports of dramatic increases in sales of guns an indication that large numbers of ordinary citizens see a utility in firearms ownership as a means of protection when public officials seem powerless to protect the population. Another dimension of the debate is often seen when particularly horrible killings occur with firearms, mass shootings in schools and workplaces are vivid, albeit rare examples. At that time the public often demands new measures designed to keep guns out of the hands of those likely to commit random acts of violence. These highly visible occurrences intensify the debate over gun control and the subsidiary debate over the meaning of the Second Amendment.

In many ways the time has come for a new debate over the Second Amendment, its meaning and how it might be applied in the twenty-first century. The idea that the right to keep and bear arms was meant to be tied so closely to membership and participation in a militia over which the government has total power to organize or fail to organize is one that can only be sustained through a highly strained reading of the history. Like nineteenth century jurist Thomas Cooley we also believe that such a reading creates a right that the government can defeat at any time simply by the way it decides to organize the militia. We would accept no such reading with any other provision of the Bill of Rights, nor should we with the Second Amendment.

But to say that the individual rights reading of the Second Amendment is the more plausible and stronger reading of the provision should not end debate on the issue. There should be a debate over whether or not the amendment should simply be repealed. Clearly many advocates of strong gun 
control measures believe the amendment to be an anachronism, a relic of an atavistic age of universal militias, posses, slave patrols, vigilantes and citizens armed against each other. If so they should make that case. It is a hard case to make in an America with widespread gun ownership and some forty-four states that have enacted or re-enacted right to bear arms provisions in their state constitutions in the twentieth century, but in the final analysis radical constitutional change should be the result of sustained debate and amendment, not simply ignoring or creatively reinterpreting key constitutional provisions.

There is however an even more interesting debate that might be had with respect to public safety and the right to bear arms. That debate would involve examining how best to recognize and protect the right while also allowing legislatures leeway to develop criminologically sound measures designed to limit, in so far as possible, access to weapons on the part of career criminals and those who are mentally unstable. Such a debate would involve recognizing that the right to have arms has been and remains part of the American Constitutional tradition, that it is valued by large segments of society and that the right sets real limits on governmental regulation. It also involves recognizing that measures designed to keep weapons out of undesirable hands are not necessarily inconsistent with this right. In the second half of the twentieth century, we were unable to develop this kind of debate on the national level precisely because of the effort to redefine the Second Amendment into meaninglessness, perhaps in the first half of the twenty-first century a greater willingness to recognize the Second Amendment will allow the dialogue to begin. 
Notes

1. District of Columbia v. Heller, No 07-290, Supreme Court of the United States, 2007 U. S. Lexis 12324

2.Bernard Bailyn, The Ideological Origins of the American Revolution (New York, 1967)

3. See generally Joyce Lee Malcolm, To Keep and Bear Arms: The Origins of an AngloAmerican Right (Cambridge, Ma., 1994) esp at 1-15

4.1 Wm and Mary Sess 2.c2 (1689)

5. William Blackstone, Commentaries on the Laws of England, Vol 1, Of the Rights of Persons (4 vols., London, 1765-1769; 1979 repr.), 139

6. C. M. Kenyon, ed., The Anti-Federalists (New York, 1966), 228

7. The Federalist, No. 46 (rev. ed., New York, 1961), 299

8. 1 Statutes at Large 271 (May 1792)

9. Joseph Story, Commentaries on the Constitution of the United States (2 vols., Boston, 1858; 1987 repr. 1,708

10. See Nunn v. State, 1 Georgia 243 (1846)

11. See Walter L. Fleming, ed., Documentary History of Reconstruction: Political, Military, Social, Religious, Educational and Industrial, 1865-1906 (New York, 1909, 1966 repr.) 290 
12. The most comprehensive discussion of the incorporation issue is Michael Kent Curtis' No State Shall Abridge: The Fourteenth Amendment and the Bill of Rights (New York, 1986). For an important discussion of the $39^{\text {th }}$ Congress's views concerning the Second Amendment , its applicability to the states through the Fourteenth Amendment and the importance of Reconstruction era civil rights legislation to an understanding of this issue, see Stephen P. Halbrook, Freedmen, the Fourteenth Amendment and the right to bear arms, 1866-1876 (Westport, Conn., 1998)

13. United States v. Cruikshank, 92 U.S. 542 (1876)

14. Presser v. Illinois 116 U. S. 252 (1886)

15. Thomas M. Cooley, Principles of Constitutional Law (Boston, 1898) 298, A Treatise on the Constitutional Limitations, $7^{\text {th }}$ Edition (Boston, 1903) 498-499

16. Andrews v. the State, 50 Tenn 154 (1871)

17. Don B. Kates, “Towards a History of Handgun Prohibition in the United States,” in Don B. Kates, ed., Restricting Handguns: The Liberal Skeptics Speak Out (Croton-On Hudson, N.Y., 1979), 7-30; Lee Kennett and James La Verne Anderson, The Gun in America: The Origins of a National Dilemma (Westport, Conn., 1975), 174-80

18. Salina v. Blaksley, 72 Kansas 230 (1905)

19. Lucillius A. Emery, “The Constitutional Right to Keep and Bear Arms,” Harvard Law Review, 28 (1915) 473

20. United States v. Miller, 307 U. S. 178 (1939)

21. Ibid

22. Aymette v. State 21 Tenn. 154 (1840)

23. Poe v. Ullman 367 U.S. 497 (1961)

24. Sanford Levinson, “The Embarrassing Second Amendment,” Yale Law Journal 99 (1989) 637. For a brief discussion of recent Second Amendment scholarship see our bibliographic essay included in this volume.

25. United States v. Printz 521 U.S. 898 (1997)

26. United States v. Emerson 270 F3rd 2003 (2001)

27. Silveira v. Lockyer, 312 F3rd 1052 (2002)

28. "Whether the Second Amendment Secures an Individual Right: Memorandum Opinion for the Attorney General.” August 24, 2004 found at 
http://www.usdoj.gov/olc/secondamendment2.htm 